\title{
Bodies Out of Time: Sculpting Queer Poetics and Queering Classical Sculpture in the Poetry of C. P. Cavafy
}

\section{J. L. Watson ${ }^{1}$ (D)}

Accepted: 20 March 2021 / Published online: 28 May 2021

(C) The Author(s) 2021

\begin{abstract}
Two major themes dominate the poetry of the Alexandrian poet, C. P. Cavafy: homosexual desire and Greekness, broadly defined. This paper explores the interconnectivity of these motifs, showing how Cavafy's poetic queerness is expressed through his relationship with the ancient Greek world, especially Hellenistic Alexandria. I focus on Cavafy's incorporation of ancient sculpture into his poetry and the ways that sculpture, for Cavafy, is a vehicle for expressing forbidden desires in an acceptable way. In this, I draw on the works of Liana Giannakopoulou on statuary in modern Greek poetry and Dimitris Papanikolaou on Cavafy's homosexuality and its presentation in the poetry. Sculpture features in around a third of Cavafy's poems and pervades it in various ways: the inclusion of physical statues as focuses of ecphrastic description, the use of sculptural language and metaphor, and the likening of Cavafy's beloveds to Greek marbles of the past, to name but three. This article argues that Cavafy utilizes the statuary of the ancient Greek world as raw material, from which he sculpts his modern Greek queerness, variously desiring the statuesque bodies of contemporary Alexandrian youths and constructing eroticized depictions of ancient Greek marbles. The very ontology of queerness is, for Cavafy, 'created' using explicitly sculptural metaphors (e.g. the repeated uses of the verb кó $\nu \omega$ ['to make'] in descriptions of 'those made like me') and he employs Hellenistic statues as a productive link between his desires and so-called 'Greek desire', placing himself within a continuum of queer, Greek men.
\end{abstract}

\footnotetext{
*This article was first presented at the conference 'ORDER' Art, Classicism, and Discourse, from 1755 to Today' (2019); my thanks go to the organizers of this event and to the participants for their comments and questions. Thanks also go to Sophie Ngan, Jennifer Ingleheart, George Gazis and Ioannis Ziogas for reading various versions of this article and providing feedback. I am grateful to the two reviewers at the IJCT for their constructive comments.
}

\section{J. L. Watson}

joseph.watson@durham.ac.uk

1 Department of Classics and Ancient History, Durham University, Durham DH1 3EU, UK 
E. M. Forster* famously said that Constantine Cavafy was 'a Greek gentleman in a straw hat, standing absolutely motionless at a slight angle to the universe'. ${ }^{1} \mathrm{He}$ less famously said that 'the poet is even more incapable than most people of seeing straight'. ${ }^{2}$ Although Forster almost certainly did not mean 'straight' as it is today colloquially used to describe heterosexuality, his comment about the nature of Cavafy's orientation to the world at large provides a springboard for my argument in this article. Cavafy was a queer man who lived in a decidedly un-queer age ${ }^{3}$ open about his sexuality to friends, ${ }^{4}$ but so coy about its homosexual nature that he rarely spoke openly about his desires for men (for more on the terms 'homosexual' and 'queer', see below). ${ }^{5}$ He did, however, write about them with candour and ardour in his poetry, ${ }^{6}$ which has, as one of its central themes, a profound interest in homosexual love and its remembrance. ${ }^{7}$ Another subject of Cavafian remembrance is the Greek past, broadly defined, mostly to be found in Hellenistic Alexandria, ${ }^{8}$ but also in the Roman and Byzantine worlds. Cavafy is in dialogue with many aspects of Greek culture, but has a certain fixation on the creative arts, especially the visual and plastic arts, with which his editor, Savidis, estimates Cavafy engages in around 99 of his 256 poems. $^{9}$ This article builds on two strands in current Cavafian

\footnotetext{
1 E. M. Forster, 'The Poetry of C. P. Cavafy', in Pharos and Pharillon, Richmond, 1923, pp. 91-7 (91). The striking image is repeated at p. 92 (of an archetypical Cavafian sentence) and pp. 96-7.

2 Ibid., p. 93.

3 Although Egypt did not legally prohibit homosexuality during Cavafy's lifetime, extra-legal punishments were both probable and regular; as a Greek, not an Egyptian, Cavafy's legal status would have been at best ambiguous; see S. Ekdawi, 'Cavafy's Mythical Ephebes', in Ancient Greek Myth in Modern Greek Poetry. Essays in Memory of C. A. Trypanis, ed. P. Mackridge London, 1996, pp. 33-44 (35-6).

4 E.g. his famous comment about Alexandria to Gaston Zaniniri, at R. Liddell, Cavafy: A Critical Biography, 2nd edn London, 2002, p. 181: 'where could I live better? Below, the brothel caters for the flesh. And there is the church that forgives sin. And there is the hospital where we die.'

5 Mackridge in C. P. Cavafy: The Collected Poems, ed. A. Hirst and P. Mackridge, transl. E. Sachperoglou Oxford, 2007, p. xi. Cavafy's (homo)sexuality was an open secret in Alexandria, as is attested

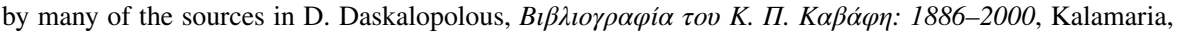
2003. Although the Alexandria of Cavafy's poetry is often not a violent place, he was subject to violent homophobic attacks, as I. A. Sareyiannis, $\Sigma \chi o ́ \lambda \iota \alpha \sigma \tau o \nu K \alpha \beta \alpha \dot{\alpha} \eta$, Athens, 1964, p. 50 points out.

${ }^{6}$ Unless otherwise stated, English titles and translations of Cavafy's poems are from C. P. Cavafy: Collected Poems, ed. G. P. Savidis, transl. E. Keeley and P. Sherrard, London, 1998; the Greek text for

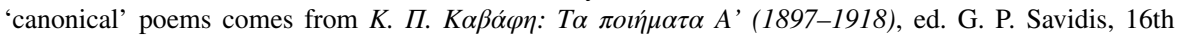

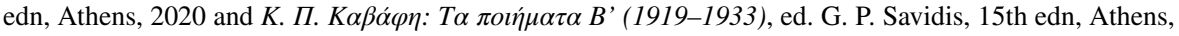
2019. All other references to Cavafy are on an ad hoc basis.

7 Cavafy's first explicitly homoerotic poem-i.e. the first poem in which his beloved's gender is grammatically masculine - is from 1919 ('On Board Ship'), fairly late into a career commencing in 1884. The beloveds of his prior poetry are not clearly gendered; although almost certainly about men, the text is not overt. The so-called 'turning-point' after which Cavafy's verse could be called 'homoerotic' is debated by scholars. 1911, 1917-1918, 1919 and 1922 have all been suggested; see D. Papanikolaou, "Words That Tell and Hide": Revisiting C. P. Cavafy's Closets', Journal of Modern Greek Studies, 23.2, 2005, pp. 235-60 (237).

8 The term 'Alexandrianism' was a byword in contemporary philology and criticism for 'degeneracy' (see Ekdawi, 'Mythical Ephebes' [n. 3 above], p. 36); Ekdawi, on p. 36, also questions whether Cavafy reappropriated the slur as modern LGBTQ+ people have reclaimed 'queer'.

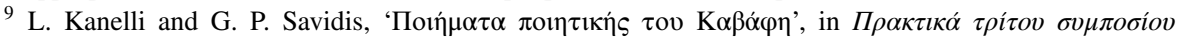

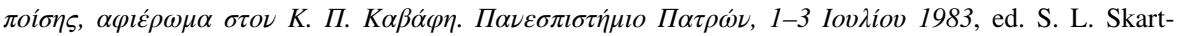

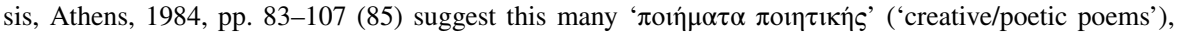


scholarship, grafting the work of Papanikolaou on queerness in Cavafy onto Giannakopoulou's research into the role of statuary and sculpture in modern Greek poetry. This paper argues that Cavafy took the apparently blank slate of his Greek past and from it sculpted a queer poetics of reception, repurposing ancient Greek art to carve out modern Greek queerness. Few of the classical sources used by Cavafy which I discuss in this article are explicitly homoerotic in the original, but some have great queer potential, on which the poet draws. Central to my discussion below is the way in which Cavafy both responds to references to classical homoerotics (such as his adoption of Platonic imagery) and queers classical images which are not inherently queer, exploiting their untapped queer potential (such as the statue of Endymion).

My argument comprises two strands which I synthesize to make a claim about Cavafian poetics. ${ }^{10}$ First, I argue that Cavafy is not only a homosexual man who wrote about beautiful men, but that his poetry is deeply concerned with queerness and queer articulations; second, I build on Giannakopoulou's thesis of sculpture as modal in Cavafy's poetry to propose that this sculptural modality constitutes a specifically queer sculptural poetics. Finally, I weave these two strands together to explore how queer themes and queer sculptural poetics operate within Cavafy's poetry, through the eroticization of sculptural bodies. When Cavafy, like a reverse Pygmalion, turns his beloveds into sculptures, he aestheticizes and eternalizes vulnerable bodies, not only in the words he writes, but in the way he writes them. To adapt Muñoz, he distils a queer ideality from the past and uses it to imagine a future: ${ }^{11}$ a potential future in which queer bodies may be un-queered and be free from the social disapproval which necessitates the poet to cloak them in marble.

\section{Queer Cavafy}

First, I will address my use of the word 'queer' and why, for the purposes of this article, I prefer it to 'homosexuality'. Undoubtedly, Cavafy was, it seems solely, attracted to other men and, if the term had been current, ${ }^{12}$ it seems likely that he

\section{Footnote 9 (continued)}

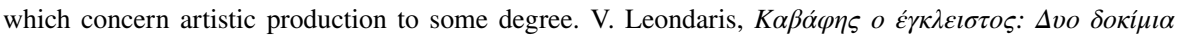

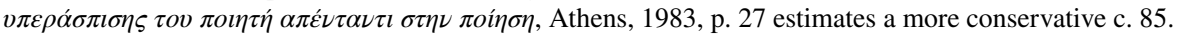

10 This article is concerned with the poetic, rather than the biographical. Although Cavafy utilizes multiple personae, all or none of which may reflect the 'real' Cavafy, there is a coherent authorial mode across the corpus (including the prose). Thus, when I talk of 'Cavafy' in relation to the speaker of the poem, I refer to the unifying literary voice, not the man.

11 J. E. Muñoz, Cruising Utopia: The Then and There of Queer Futurity, 2nd edn, New York (NY), 2019 , p. 1.

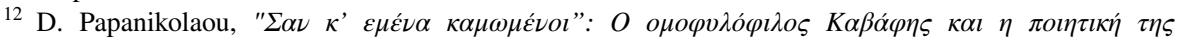
$\sigma \varepsilon \xi$ ov $\alpha \lambda$ ıкó $\eta \tau \alpha \varsigma$, Athens, 2014, p. 14 stresses two points which are of central importance to my use of the terms 'gay', 'queer', etc.: (1) the term 'gay' was not a signifier of homosexuality in Cavafy's

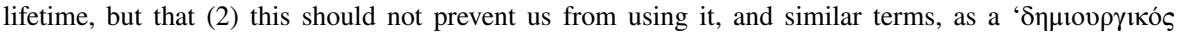

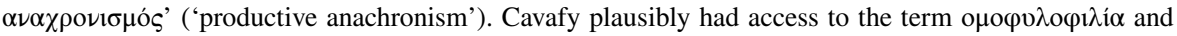
its English and French equivalents, homosexuality and homosexualité, which had been coined as the German Homosexualität by Kertbeny in 1868 (for which, see M. Herzer, 'Kertbeny and the Nameless Love', Journal of Homosexuality, 12.1, 1986, pp. 1-26) but popularized after the 1886 publication of KrafftEbing's Psychopathia Sexualis. 
would have self-identified as a homosexual man. However, where 'homosexuality' describes sexuality in terms of relationships between people, 'queerness' is an artic-

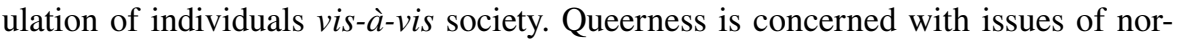
mativity and difference and is a condition marked and defined by the fact that it is not mainstream. This is the perspective from which I explore Cavafy's expression of sexuality: not merely as a man who was attracted to other men, but as a man whose identity was constituted by his 'slight angle to the universe'. The queer condition is coloured by a separation from the mainstream and a focus on identity formation, as may be seen in Cavafy's note of 1905:

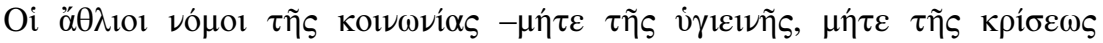
ả

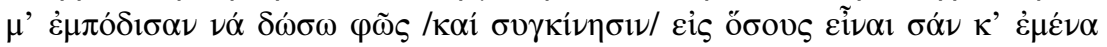

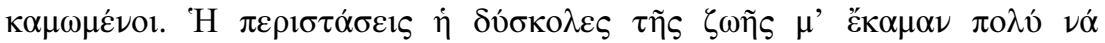

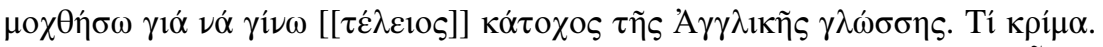

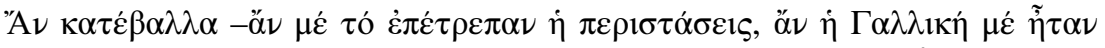
ö

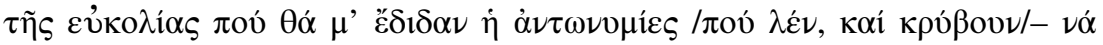

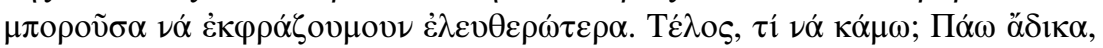

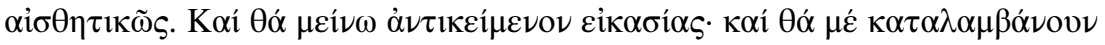

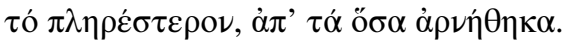

The wretched laws of society-the result of neither hygiene nor judgementhave lessened my work. They have blocked my freedom of expression; they have impeded me from giving light and emotion to those who are made just like me. The difficult circumstances of my life made it hard for me to become a [fluent] English speaker. What a shame! If I put the same struggles in French, maybe I could have expressed myself more freely, because of the ease with which the pronouns both reveal and conceal-if circumstances had allowed me, if the French tongue was just as useful to me... But, what can I do? I'm wasting away, aesthetically. And I will remain the object of conjecture; and they will understand most deeply from the things I denied. ${ }^{13}$

From the first words of the note ('the wretched laws of society'), Cavafy has marked himself as separate from and, in some sense, in opposition to the customs of those around him. Instead, he has carved out for himself a different community, con-

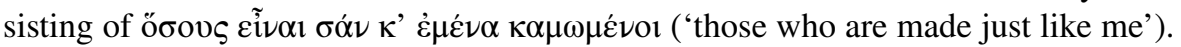
When Cavafy employs forms of the verb kó $v \omega$, he often uses it in a similar sense to

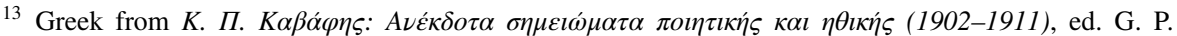
Savidis, Athens, 2009, p. 36 ('Note 13'); translation, mine. This short prose note provided the title for Papanikolaou's $\Sigma \alpha \nu \kappa$ ' $\varepsilon \mu \varepsilon ́ \nu \alpha \kappa \alpha \mu \omega \mu \varepsilon ́ \nu o r$ (n. 12 above); see his pp. 117-19. Cf. a similar idea in 'Hidden

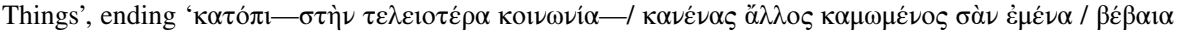

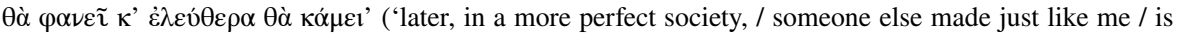

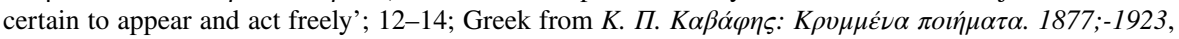
ed. G. P. Savidis Athens, 1993. Cf. Cavafy's blaming of society for queerphobia (not queerness per se) in 'Days of 1896'.
} 
$\pi \lambda \dot{\alpha} \theta \omega$ (see below); it takes on the sense of 'create' and connotes a constructed state

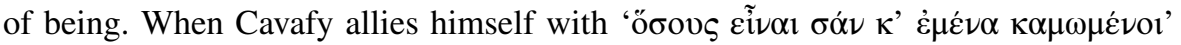
('those who are made just like me'), he places himself as part of a group identity, by which he clearly means 'queer' or 'homosexual'. ${ }^{14}$ Cavafy's poetry rarely presents us with clear images of a 'queer subculture', as it were, but an obvious example where such a trope obtains is 'In a town of Osroini':

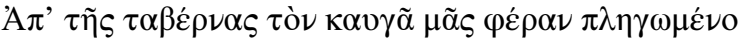

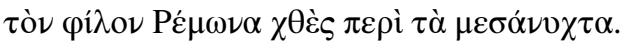

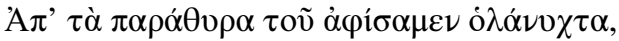

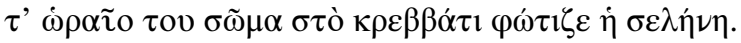

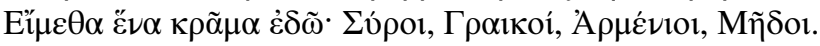

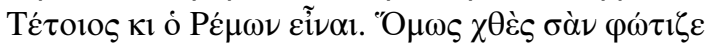

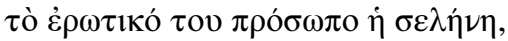

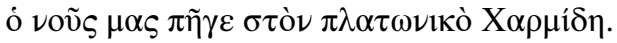

Yesterday, around midnight, they brought us our friend Remon, who'd been wounded in a taverna fight.

Through the windows we left wide open,

the moon cast light over his beautiful body as it lay on the bed.

We're a mixture here: Syrians, immigrant Greeks, Armenians, Medes.

Remon is one of these too. But last night,

when the moon shone on his sensual face,

our thoughts went back to Plato's Charmidis.

This poem sees the Cavafian persona, together with a group of multiracial friends,

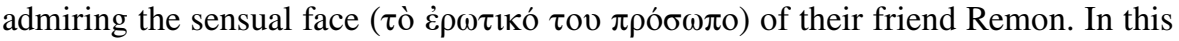
poem, the group is unified by their diversity; this diversity is usually translated with reference to the group's racial variation, ${ }^{15}$ but the phrase $\varepsilon^{2} \nu \alpha \kappa \tilde{\alpha} \mu \alpha$ does not only specify racial intermingling. It is an image from metallurgy, referring to an alloy of two or more metals. ${ }^{16}$ The sense is one of a new entity formed out of other things,

\footnotetext{
${ }^{14}$ The verb is used in the same way, as I suggest above, at 'Chandelier', 9 and 'Hidden things', 13. It is otherwise used of sensualized artistic production in Cavafy at, e.g., 'Picture of a 23-year-old painted by his friend of the same age, an amateur'. Cf. the verb's phrasal meaning 'to carve something out for oneself'.

15 E.g. Sachperoglou's 'we are a mixture of races here' (Hirst and Mackridge C. P. Cavafy [n. 5 above], p. 93), Zervos and Portier's 'nous sommes une ville de sang-mêlé' (Cavafy: Euvres Poétiques, ed. M.-C. Char, transl. S. C. Zervos and P. Portier, Paris, 1992, p. 60) and Yourcenar's 'Ici, nous sommes tous de race mixte, mélange de sang...' (Constantin Cavafy: Poèmes, ed. M. Yourcenar, tran. M. Yourcenar and C. Dimaras, Paris, 1978, p. 133).

16 There is a possible reference to bronze sculptures in Cavafy's use of metallurgic imagery here. Metal statues are generally rare in Cavafy (there are chryselephantine statues in 'Apollonios of Tyana in Rhodes' and an allusion to them in 'The funeral of Sarpedon'; see L. Giannakopoulou, 'Moulded by Eros with Skill and Experience: Sculpture of the Male Body in the Poetry of Cavafy', Dialogos: Hellenic Studies Review, 7.1, 2001, pp. 78-98 (84); L. Giannakopoulou, The Power of Pygmalion: Ancient Greek Sculpture in Modern Greek Poetry, 1860-1960, Bern, 2007, pp. 115-16). Cavafy preferred stone, especially marble (see Giannakopoulou 'Moulded by Eros', 82). Sculptural suggestion here would underscore my argument of the interconnectedness of sculpture and queerness in Cavafy.
} 
defined by, but different from, its composite parts. This alloy could also be seen as a queer community, bridging racial differences in favour of a shared experience: the contemplation of the beautiful young Remon. The action is collective, stressed by the first-person plural verbs and pronouns ( $\left.\mu \alpha \varsigma, \alpha \dot{\alpha} \varphi \dot{\sigma} \sigma \alpha \mu \varepsilon \nu, \varepsilon{ }^{\prime \prime} \mu \varepsilon \theta \alpha\right)$, and the use of the singular o voũs, a singular mentality shared by the whole group. ${ }^{17}$ The queerness of this scene is immediately apparent from how the collective gazes upon Remon as a sight, posed dramatically in the moonlight, ${ }^{18}$ but is heightened when we unpack the nature of that sight. Remon's is a brutalized body and, beyond a mention of a tavern brawl, no cause is given to this. Given this poem's focus on queer community and evocation of Classical homoerotic subtext (see below), I propose that it is possible to see Remon's body as one brutalized in homophobic violence, which is brought back to his queer family. The community then cares for the victim, sharing in sympathy for violence which they could imagine affecting any one of them.

'Osroini's queerness is also constituted by the classicizing reference to Plato. The Charmides is a Platonic dialogue about $\sigma \omega \varphi \rho \sigma v \nu$ ' ('temperance'), in which the principal characters are Socrates and the ephebic youth, Charmides. Socrates's homoerotic attraction to Charmides is repeatedly stressed in the dialogue; perhaps most relevant to a discussion of 'Osroini' is Socrates's description upon seeing the youth:

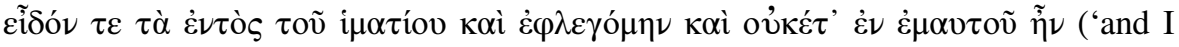
saw what was within his cloak and I burned with passion and was no longer within myself'; Pl. Chrm. 155D). ${ }^{19}$ As they gaze on a beautiful body, Cavafy's constructed queer community collectively 'remember' the homoerotically charged Platonic text in which another figure looks desirously at the male form. ${ }^{20}$ I see this poem as indicating

\footnotetext{
17 See R. Dellamora, 'Greek Desire and Modern Sexualities', in Imagination and Logos: Essays on C. P. Cavafy, ed. P. Roilos, Cambridge (MA), 2010, pp. 121-42's notion that homosocial 'fellowship' in Cavafy 'carries a coded, personal signification of a group of young men, joined by the shared sensation and affects of male intimacy' (p. 126) and that it creates 'transnational affinity groups, affiliated though shared linguistic, aesthetic, and sexual tastes' (p. 128).

$18 \mathrm{Cf}$. 'Before the statue of Endymion', in which there is another erotic, semi-clothed, male body recumbent; see my discussion below. The presence of $\dot{\eta} \sigma \varepsilon \lambda \dot{\eta} \nu \eta$ ('the moon') in 'Osroini' figures the absent presence of the goddess Selene in 'Endymion', connecting the body of Remon to other queered bodies in Cavafy's oeuvre.

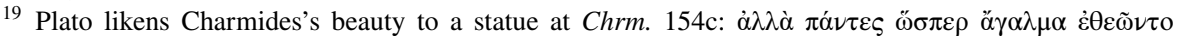
$\alpha$ ‘́óv ('but we are all gazing at him like a statue'); cf. the presentation of queer lovers as statues in Plato's Symposium (e.g. 215a-b; 216d-217a). For (homo)erotic statue imagery in Plato, see D. Steiner, 'For Love of A Statue: A Reading of Plato's Symposium 215A-B', Ramus, 25.2, 1996, pp. 89-111.

${ }^{20}$ Cavafy's queer alloy may also be remembering Wilde's 1881 poem 'Charmides', which is also rich in queer subtexts; C. P. Cavafy: Complete Poems, ed. \& transl. D. Mendelsohn, London, 2012, pp. 511-12 discusses the potential intertexts between Wilde and Cavafy. Cavafy's poem was initially entitled 'Charmides' and was later changed to 'In a town of Osroini', which lends credence to this intertextual interpretation; Ekdawi 'Mythical Ephebes' (n. 3 above), p. 42 suggests that the name change may have been a deliberate attempt on Cavafy's part to cloak the reference to Wilde and his renowned homosexuality. For the trope of a reading of Plato proving central to discovering modern queerness, see my n. 61. Cf. also Philip Gillespie Bainbrigge's play Achilles in Scyros: A Classical Comedy (1912), in which a queered Achilles plays the part of 'a pretty boy; they call him Charmides' (350); see J. Ingleheart, Masculine Plural: Queer Classics, Sex, and Education, Oxford, 2018, pp. 271-73.
} 
that Cavafy may have conceived of his queer identity as something not unique to himself, which participated in a queer continuum dating back to Plato. ${ }^{21}$

Many of Cavafy's poems are concerned with articulating his queer 'slight angle to the universe'; in these, he withdraws from common society into a self-imposed exile, sculpting out his own role as an outsider to society. Cavafy was a solitary figure whose poetics are markedly concerned with separation between public and private, mundane and artistic, societal expectation and poetic nonconformism. ${ }^{22}$ In poems such as 'Walls', Papanikolaou has identified the isolated space within the self-imposed rooms of Cavafy's poetry as a sort of 'closet', in which the poet is bound by his sexuality, ${ }^{23}$ but also from which he is able to negotiate the terms of the disclosure of his (homo)sexuality. ${ }^{24}$ A prime example of this Cavafian negotiation of disclosure may be found in his letters to Forster. In a letter dated 4 August 1922, ${ }^{25}$ Cavafy implores Forster to edit his article 'The Poetry of C. P. Cavafy' between publications; the original version of the article, published in The Athenaeum, ${ }^{26}$ describes the object of 'In the month of Athyr' as 'a boy of sixteen' (248). The age is simply a mistake-Cavafy's Greek prints 'Kó $\pi \pi \alpha$ Z $\tilde{\tau} \tau$ ' on line 5, which means 27, not 16-but Cavafy is particular about the term 'boy', writing 'naturally, the word "boy" to be replaced by some other term'. Forster clearly understood Cavafy's insinuation and, in the article's reprint in Pharos and Pharillon, he corrected to 'a young man'. ${ }^{27}$

\footnotetext{
${ }^{21}$ Cavafy was aware of how his queerness was intricately related to his literary and cultural inheritance from the classical world; see D. Papanikolaou, 'Days of Those Made like Me: Retrospective Pleasure, Sexual Knowledge, and C. P. Cavafy's Homobiographics', Byzantine and Modern Greek Studies, 37.2, 2013, pp. 261-77. Cf. 'Note 12' (Savidis, $\Sigma \eta \mu \varepsilon ı \omega \mu \alpha \tau \alpha$ [n. 13 above], p. 35), in which Cavafy argues

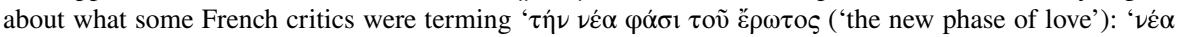

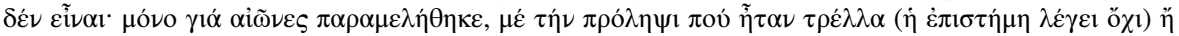

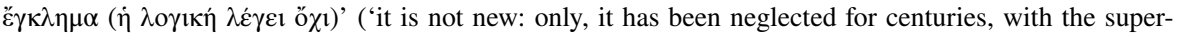
stition that it was madness [science says otherwise] or criminal [reason says otherwise]'). In addition to Wilde, Swinburne, Pater and Winckelmann, Cavafy was familiar with the writings of the poet and early homosexual theorist John Addington Symonds; see Papanikoloaou, $\Sigma \alpha \nu$ ' $\varepsilon \mu \varepsilon ́ \nu \alpha \kappa \alpha \mu \omega \mu \varepsilon ́ \nu o \imath$ (n. 12 above), pp. 91-137 and Mendelsohn, C. P. Cavafy (n. 19 above), pp. 565-6.

${ }^{22}$ For the importance of such polarities (and others) to the constitution of queerness, see E. Kosofsky Sedgwick, The Epistemology of the Closet, Berkeley (CA), 1990, p. 11.

23 For issues of space, especially the inside/outside dichotomy in Cavafy, see R. S. Peckham, 'Cavafy and the Poetics of Space', Journal of the Hellenic Diaspora, 17.1, 1991, pp. 37-48. See also M. Doty, 'Cavafy's Rooms', in Imagination and Logos: Essays on C. P. Cavafy, ed. P. Roilos, Cambridge (MA), 2010, pp. 143-51.

24 Papanikolaou 'Words That Tell and Hide' (n. 7 above), p. 238. See also E. Kosofsky Sedgwick, 'Cavafy, Proust, and the Queer Little Gods', in The Weather in Proust, ed. J. Goldberg, Durham

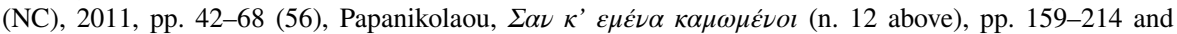

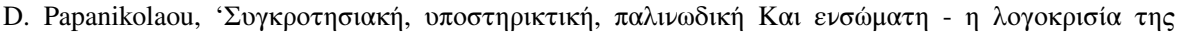

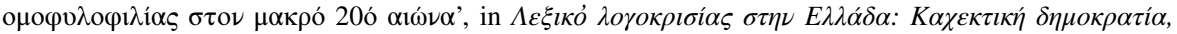
$\delta i \kappa \tau \alpha \tau o \rho i ́ \alpha, \mu \varepsilon \tau \alpha \pi о \lambda i \tau \varepsilon v \sigma \eta$, ed. P. Petsini and D. Christopoulos, Athens, 2018.

25 P. Jeffreys, The Forster-Cavafy Letters: Friends at a Slight Angle, Cairo, 2009, p. 47.

26 E. M. Forster and G. Valassopoulo, 'The Poetry of C. P. Cavafy', The Athenaeum, 4643, 1919, pp. 247-48.

27 E. M. Forster, 'The Poetry' (n. 1 above), p. 96. Of those classical scenes on which Cavafy draws containing is male-male desire, it is almost exclusively part of a pederastic union (for which, see K. Dover, Greek Homosexuality, 2nd edn, Cambridge (MA), 1989; D. M. Halperin, One Hundred Years of Homosexuality and Other Essays on Greek Love, New York (NY), 1990, especially pp. 15-54); due to the intrinsic power imbalance, this is not equivalent to modern homosexuality. Despite his identification with
} 
Cavafy, then, positions himself on the edge of society, looking in at it from a queer angle; in 'Chandelier', ${ }^{28}$ Cavafy defines himself and his desire as something other and deviant in the eyes of $\tau$ ò $\sigma 0 \nu \varepsilon \imath \theta \imath \sigma \mu \varepsilon$ 'vo ('the ordinary' or, perhaps, 'heterosexual'). His desires are characterized as not made for $\alpha$ ' $\sigma \alpha \mu \alpha \sigma \omega ́ \mu \alpha \tau \alpha$ ('timid bodies'), ${ }^{29}$ and therefore as desires which require $\tau o ́ \lambda \mu \eta$ ('daring') and which run a rough, countercultural course. Whether such a stance was pure poetics or 'real' biography is immaterial; his poetics display him as existing parallel to his Alexandrian community, not thriving within it. This mode is perhaps clearest in 'Growing in Spirit':

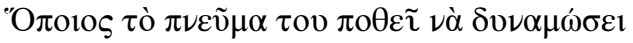

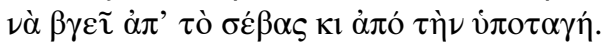

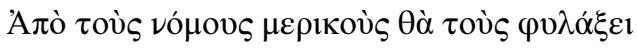

$\dot{\alpha} \lambda \lambda \grave{\alpha} \tau$ ò $\pi \varepsilon \rho 1 \sigma \sigma o ́ \tau \varepsilon \rho o \theta \dot{\alpha} \pi \alpha \rho \alpha \beta \alpha i ́ v \varepsilon 1$

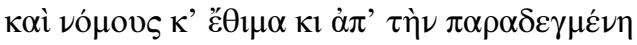

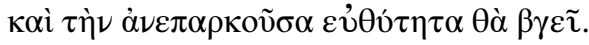

A $\pi$ ò $\tau \dot{\varepsilon} \varsigma \dot{\eta} \delta o \nu \grave{\varepsilon} \varsigma \pi \mathrm{o} \lambda \lambda \dot{\alpha} \theta \dot{\alpha} \delta 1 \delta \alpha \chi \theta \varepsilon \tilde{\mathbf{z}}$.

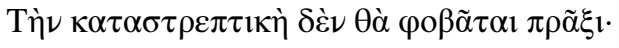

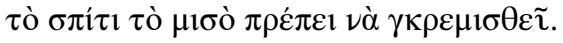

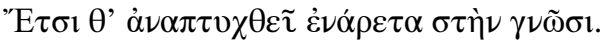

He who hopes to grow in spirit

will have to transcend obedience and respect.

He'll hold to some laws

but he'll mostly violate

both law and custom, and go beyond

the established, inadequate norm.

Sensual pleasures will have much to teach him.

He will not be afraid of the destructive act:

half the house will have to come down.

This way he will grow virtuously into wisdom. ${ }^{30}$

\footnotetext{
Footnote 27 (continued)

participants in this system, Cavafy, in this letter and elsewhere, takes pains to stress the adulthood of his beloveds; see e.g. 'Two young men, 23 to 24 years old'. In doing so, Cavafy cherry-picks some aspects of 'Greek love', without importing its more problematic features.

28 Ekdawi, 'Mythical Ephebes' (n. 3 above), p. 35 detects visual parallels between the chamber described in 'Chandelier' and the bedroom of Alfred Taylor, which was depicted luridly in the British press after he went on trial alongside Oscar Wilde in 1895 for gross indecency. Ekdawi also elucidates that 'Chandelier' was written in the same month that these news stories broke. If we follow the connection Ekdawi makes, we see Cavafy establishing a queer sympathy with other men whom he sees as subject to the same desires as himself. Cavafy left a note on the poem (F88, $\varphi 29$; see n. 45) in which he characterizes the room in 'Chandelier' as representing an extreme youthful zeal for eroticism but a zeal which requires some degree of courage to be realized.

29 Again, Cavafy's desires are presented with a form of the verb кó $\nu \omega$ ('to make'), for which, see below.

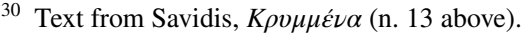


Cavafy is here unabashedly countercultural, holding reverence for neither vó $\mu$ oı

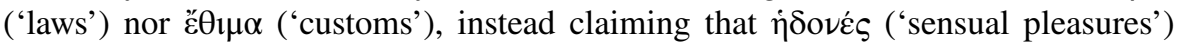

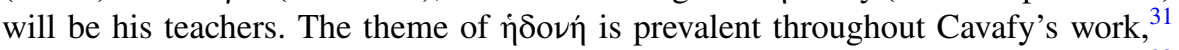
and often, as here, it is implicitly tied up with specifically homoerotic pleasure. ${ }^{32}$ Pleasures, as Jeffreys elucidates, are almost always attached to $\dot{\alpha} \lambda$ yo ('pains'). ${ }^{33}$ Pains and sickness are ubiquitous in Cavafy's poetry, picking up on the Classical trope of love-as-sickness; ${ }^{34}$ however, sickness in Cavafy is queered and is specifically used to describe queer love. ${ }^{35}$ Indeed, it is fairly common for Cavafy to use a variation on 'unhealthy love' as analogic for 'queer'; for instance, in 'In an old book', Cavafy examines a homoerotic watercolour painting, of which he says ' $\tilde{\eta} \tau \alpha \nu$

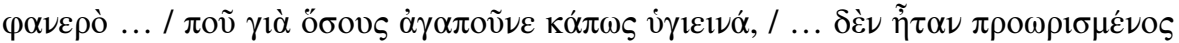

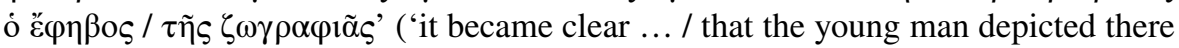
/ was not destined for those / who love in ways that are more or less healthy'; 7-12). Similarly, in 'The twenty-fifth year of his life', queer love is pathologized as a sick-

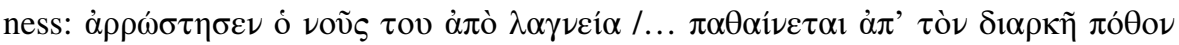

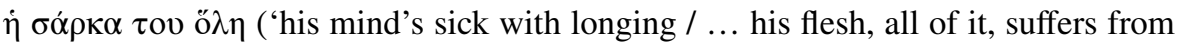
endless desire'; 13-15). There exists, then, in Cavafy's poetics, a tension between

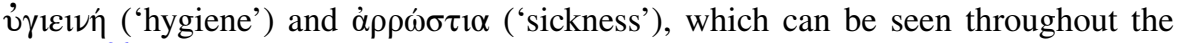
corpus: ${ }^{36}$ the 'sanitary' or 'healthy' in Cavafy represents heterosexual normativity, whereas 'sickness' is constitutive of deviant queer desire. ${ }^{37}$

\footnotetext{
${ }^{31}$ P. Jeffreys, “'Aesthetic to the Point of Affliction": Cavafy and English Aestheticism', Journal of Modern Greek Studies, 24.1, 2006, pp. 57-89 (63) detects a Swinburnian influence on Cavafy in his use

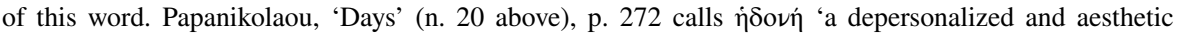
" $\eta \delta o v \eta$ " lying outside but ready, like a vampire, to claim $a$ body', reinforcing the externality of the $\dot{\eta} \delta o v \varepsilon \dot{\varepsilon}$ which allows them to be teachers, not solely internal emotions.

32 E.g. 'Imenos', 2; 'Their beginning', 1; 'In despair', 8, 9; 'Theatre of Sidon (A. D. 400)', 7; 'In the boring village', 12; 'Days of 1901', 10; 'A young poet in his twenty-fourth year', 10. Cf. the use of the

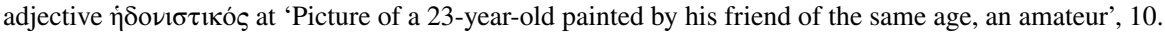

33 Jeffreys, 'Aesthetic' (n. 30 above), p. 63.

${ }^{34}$ E.g. Sapph. fr. 31; Catull. 76; Hor. Carm. 1.13.5-6; Prop. 1.5.21-2; the framing of Ov. Rem. as a 'cure' for the 'sickness' of love. For discussion of the trope, see J. Booth, 'All in the Mind: Sickness in Catullus 76', in The Passions in Roman Thought and Literature, ed. S. M. Braund and C. Gill Cambridge, 1997, pp. 150-68 (153-60).

${ }^{35}$ E.g. 'In and old book', 'In despair', 'Melancholy of Jason Kleander, poet in Kommagini', 'Imenos', 'Kleitos' illness' and 'To have taken the trouble'.

${ }^{36}$ E.g. the above-cited 'Note 13'.

${ }^{37}$ In Cavafy's queering of this typical love-motif, there may be an allusion to fin-de-siècle sexology: as noted above, Cavafy was familiar with the work of Symonds and with the sexology movement

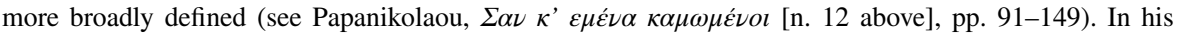
pathologizing of queerness, Cavafy may allude to the way that writers like Ellis or Krafft-Ebing con-

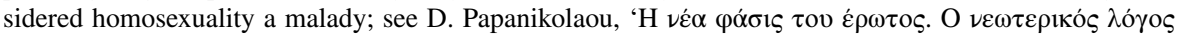

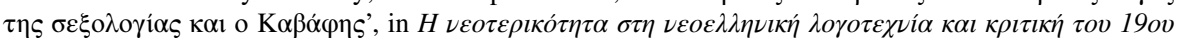

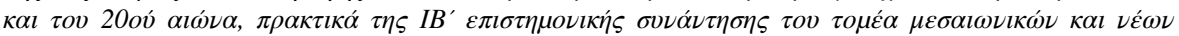

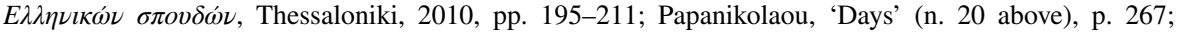

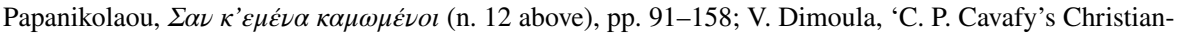
ity in the Context of Fin de Siècle Discourses on Pleasure: The Vicissitudes of Reinvented Love', Journal of Modern Greek Studies, 37.1, 2019, pp. 149-78. For so-called 'nosology' in Cavafy, see M. Vassi-

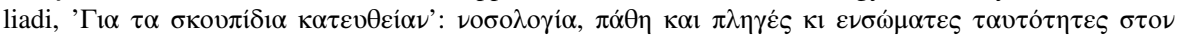

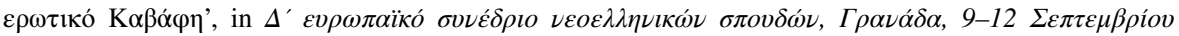


By examining the dynamics of these two themes (pleasure and sickness), it becomes clear that Cavafy's is not a poetry of the present, but of the present remembering a lost and irretrievable past, a 'hedonalgic' moment bifurcated between the sexual delights of youth and the wise reflections of old age. My coinage-hedonalgia (literally $\dot{\eta} \delta o \nu \eta ் ~+\not \alpha \lambda \gamma o \varsigma$ ) -is an attempt to capture Foucault's diagnosis of the queer condition, spelled out in an interview with James O'Higgins:

...for a homosexual, the best moment of love is when the lover leaves in the taxi. It is when the act is over and the boy is gone that one begins to dream about the warmth of his body, the quality of his smile, the tone of his voice. It is the recollection rather than the anticipation of the act that assumes a primary importance in homosexual relations. ${ }^{38}$

Most frequently, the hedonalgic mode sees the Cavafian persona gazing back from an experienced position of seniority and re-examining the wild sensuality of his youth, ${ }^{39}$ however, this article is concerned with Cavafy's 'memories' of the ancient world. As I suggested above, Cavafy's queer hedonalgia sometimes looks beyond the fleeting pleasures of the poet's own youth to the homoeroticisms of the Hellenistic age. He sees, in the ancient Greek world, analogues for the sort of desire he experiences in twentieth-century Alexandria and recognizes ephebic, ${ }^{40}$ often Alexandrian, youths from antiquity as interchangeable with the objects of his own desire. The past is a canvas of potentiality onto which Cavafy can project his understanding of his sexuality, and from which he can extract inspiration. This is clearly expressed in 'Days of 1909, '10, and '11'; in the first two stanzas, Cavafy describes a poor ironmonger and sex worker to whom he is attracted, recounting in some detail the trappings of poverty, such as the man's torn shoes. In the third stanza, the poet directly melds the twentieth-century youth - the period is emphasized by the poem's title $^{41}$ — with an imagined beauty of antiquity:

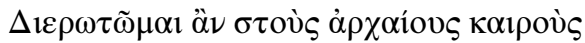

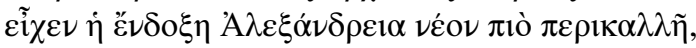

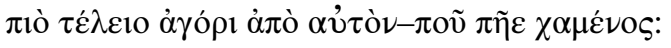

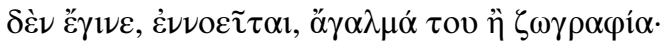

\footnotetext{
Footnote 37 (continued)

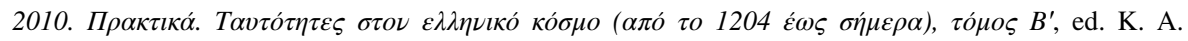
Dimadis, Athens, 2011, pp. 803-11.

${ }^{38}$ J. O'Higgins and M. Foucault, 'Sexual Choice, Sexual Act: An Interview with Michel Foucault', Salmagundi, 58-59, 1982-1983, pp. 10-24 (19).

${ }^{39}$ E.g. 'Since nine o'clock', 'Come back', 'Very seldom', 'Long ago', 'One night', 'In the evening', 'Grey', 'I've looked so much...', 'Body remember...', 'Understanding', 'The next table', 'The afternoon sun', 'Comes to rest', 'On board ship', 'To call up the shades', 'Their beginning', 'I've brought to art', 'The twenty-fifth year of his life', 'In the tavernas', 'December 1903', 'At the theatre'. Although not explicitly sensual, other poems capture similar emotions, such as 'An old man', 'Candles', 'Voices'; these poems are notably earlier, which may explain the vagueness of the object of the hedonalgic gaze.

${ }^{40}$ See especially Ekdawi, 'Mythical Ephebes' (n. 3 above).

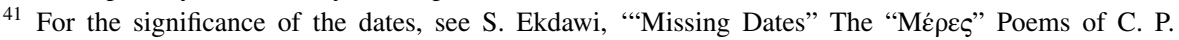
Cavafy', Byzantine and Modern Greek Studies, 35.1, 2011, pp. 70-91 (especially 88-9).
} 
I ask myself if the great Alexandria

of ancient times could boast of a boy

more exquisite, more perfect-thoroughly neglected though he was:

that is, we don't have a statue or painting of him; ${ }^{42}$

The relationship between queerness and temporality has long been documented by queer theorists. ${ }^{43}$ Indeed, 'queer connections are frequently brought about by acts of bending time, productive mobilisations of anachronism, and momentary or sustained transitions from temporal normativities into osmotic temporalities'. ${ }^{44}$ Manipulation of temporalities and exploration of different temporal potentialities is a particularly queer literary phenomenon and Cavafy's evocation of the ancient world and injection of it into the early twentieth century demonstrates the sorts of aesthetic sympathies which Muñoz diagnoses as belonging to a conception of the present 'in relation to the alternative temporal and spatial maps provided by a perception of past and future affective worlds' ${ }^{45}$ In Cavafy's conjuring of the ancient boy in this poem, he melds past and present to synthesize an affective poetic reality of transhistorical queer sentiment.

This synthesis is reflected even at the linguistic level, where the demotic Greek word $\dot{\alpha} \gamma o ́ p ı$ describes the imaginary ancient youth and the classicising katharevousa form $\pi \varepsilon \rho \iota \kappa \alpha \lambda \lambda \dot{\eta}$ is applied to the modern, flesh-and-blood young man. In fusing the youths, Cavafy's queer lens comes up against the men's differing social contexts: he wrote in a note on the poem that the beautiful youth of Alexandria past was free of the constraints of social opprobrium towards homosexual love, and thus could have statues and paintings made of his beauty, whereas the ironmonger could have no such commemoration. ${ }^{46}$ The terms of the youth's commemoration are explicitly sculptural; Cavafy establishes statuary as a means by which queer love can survive the ravages of time. The reference to statuary sets up the theme on which the remainder of this article will focus, namely, how Cavafy uses real or imagined sculpture from the ancient Greek world to frame and explicate his desires. Temporal displacement as a mode of conceiving of the youths whom Cavafy desires is ubiquitous within the Cavafian corpus, as is illustrated in 'On board ship', 9-10:

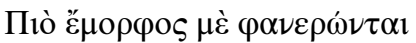

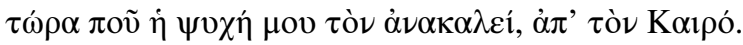

42 'Days of 1909, '10, and '11', 13-16.

${ }^{43}$ E.g. Muñoz, Cruising Utopia (n. 11 above); L. Edelman, No Future: Queer Theory and the Death Drive, Durham (NC), 2004.

${ }^{44}$ S. Matzner, 'Queer Unhistoricism: Scholars, Metalepsis, and Interventions of the Unruly Past', in Deep Classics: Rethinking Classical Reception, ed. S. Butler, London, 2016, pp. 179-202 (192).

${ }^{45}$ Muñoz, Cruising Utopia (n. 11 above), p. 27.

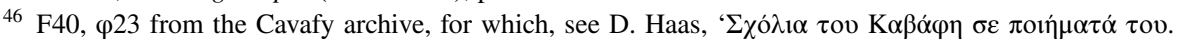

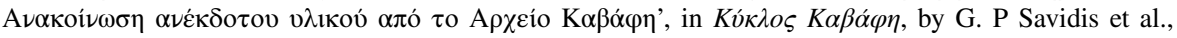
Athens, 1983, pp. 83-109 (105-6). For the reference system of the archive, see G. P. Savidis and M.

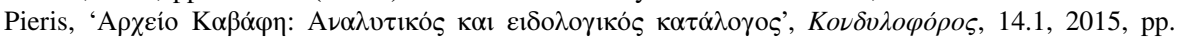
$217-395$. 
He appears to me better looking

now that my soul brings him back, out of Time.

Just as the youth in 'On board ship' is pulled 'out of Time' through a sketch, the statuesque youths in the poems which I discuss in this article are pulled 'out of Time' through references to the ancient world.

\section{Sculpture}

Cavafy's poetry is deeply concerned with sculptural imagery, ${ }^{47}$ language and themes; sculptural motifs in Cavafy have been well examined by Giannakopoulou, so I shall dwell on them only briefly here. Giannakopoulou focuses on how sculpture is an instrument of modern Greek poetics: "for many Greeks, particularly in the nineteenth century... sculpture becomes the symbolic incarnation of liberty and the justification of [modern Greece's] very existence". ${ }^{48}$ However, I propose a different and specifically queer articulation of the theme of sculpture in Cavafy's poetics. First, in this section, I explore how Cavafy generally uses statuary to articulate a connection to the ancient world, before, in section three, proposing a queer orientation of sculpture.

Cavafy's mot juste for creative activities is $\tau \dot{\varepsilon} \chi \nu \eta$ ('art'), often capitalized to imbue it with quasi-divine power. ${ }^{49}$ The first thing which must be said about such a loaded word is that it is even broader than English's already capacious term 'art'; $\tau \dot{\varepsilon} \chi \nu \eta$ can refer to a massive range of artistic or crafting pursuits, ${ }^{50}$ and in Cavafy is interchangeably applied to poetry, sculpture and painting. ${ }^{51}$ For my purposes, I concern myself only with its sculptural meanings. Giannakopoulou estimates that Cavafy's 'sculpture-related corpus' constitutes some 20 poems, ${ }^{52}$ although this may be a conservative estimate, due to the centrality of sculpture to his poetics. Giannakopoulou also details how Cavafy's process of artistic production directly mirrors the creative process of a sculptor, ${ }^{53}$ namely: he works slowly, often leaving many years between a poem's inception and its publication; ${ }^{54}$ he takes a lengthy work, and slowly shaves and thins it down to a smoother and more refined piece of art; he conceives of poetry as a physically statuesque thing, describing it as $\lambda \varepsilon \tilde{\tau}$ os

\footnotetext{
${ }^{47}$ For Cavafy, sculpture is an almost exclusively male, and thus homoerotic, phenomenon. Women are generally minor characters in Cavafy's poetry, but this is even more pronounced in his depictions of sculpture, as there is only one sculpted woman in the corpus: Rhea Silvia in 'Sculptor of Tyana', 6-7.

48 Giannakopoulou, 'Moulded by Eros' and Power of Pygmalion (n. 16 above), p. 32.

49 E.g. 'Of the Jews (A.D. 50)', 14, 'Melancholy of Jason Kleander, poet in Kommagini', 4 and 'I've brought to art', 2.

50 Indeed, G. Jusdanis, The Poetics of Cavafy: Textuality, Eroticism, History, Princeton (NJ), 1987, p. 100 sees Té $\chi \nu \eta$ as meaning something like Weltanschauung ('worldview') for Cavafy.

51 Ibid., p. xii.

52 Giannakopoulou, 'Moulded by Eros' (n. 16 above), p. 78.

53 Ibid., p. 78-80.

54 Something which Giannakopoulou likens to Adrian Stokes's concept of 'Weathering' — see A. Stokes, Stones of Rimini, New York (NY), 1969, p. 28 n. 1.
} 
('polished'). ${ }^{55}$ Significantly, Cavafy repeatedly uses sculptural vocabulary when describing the process of imaginative creation. The verbs $\pi \lambda \alpha \theta \omega$ ('to mould') and $\sigma \chi \eta \mu \alpha \tau i \zeta \omega$ ('to form') are ubiquitous in his work; ${ }^{56}$ in addition, the verb кó $\nu \omega$, though not exclusively sculptural, is extremely frequent in Cavafy's poetry, with a clear sense of 'to make' or 'to craft' in an artistic manner. This motif is especially well expressed in the famous poem 'Kaisarion':

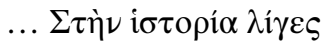

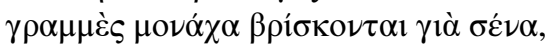

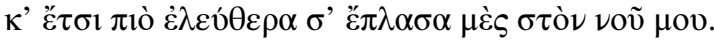

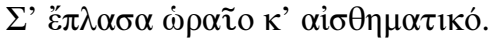

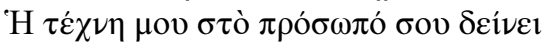

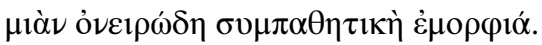

Because so little

is known about you from history,

I could mould you more freely in my mind.

I moulded you good-looking and sensitive.

My art gives your face

a dreamy, appealing beauty.

[Italics denote my alterations to Keeley \& Sherrard's translation] ${ }^{57}$

In this poem, Cavafy calls up a ghost of the Alexandrian prince Kaisarion, at

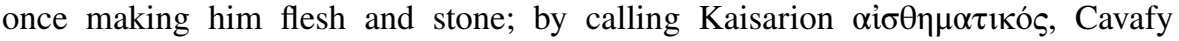

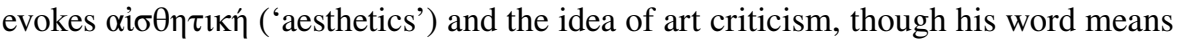
'sensitive'. Although the boy is imagined to be alive in Cavafy's transhistorical evocation, he is also cast as something $\pi \lambda \alpha \sigma \mu \varepsilon \dot{\nu}$, sculpted out by Cavafy's $\tau \dot{\varepsilon} \chi \nu \eta$, to become himself a $\tau \dot{\varepsilon} \chi \nu \eta{ }^{58}$ In a way which is reminiscent of my earlier comments on the verb кó $\nu \omega$, Cavafy here uses sculptural metaphor, not only to describe a highly eroticised body, but also to explicate the process of literary poiesis. ${ }^{59}$ In the Cavafian

\footnotetext{
55 'For Ammonis, who died at 29, in 610', 3. The motifs of slimming down, hard work and polishing are reminiscent of the Hellenistic aesthetics of poetry and poetic process, deployed by, e.g., Callimachus and his Roman imitators. We must, therefore, be alert to this allusion in Cavafy's poetics. Indeed, Cavafy's $\lambda \varepsilon \tilde{\tau}$ os artfully evokes Catull. 1.1's lepidus, which, in turn, picks up on Call. Aet. fr. 1.11's $\lambda \varepsilon \pi \tau$ ó $\varsigma$ (see N. Hopkinson, A Hellenistic Anthology, Cambridge, 1988, p. 98). For slimming, see e.g. Call. Aet. fr. 1; Virg. Ecl. 6.3-5; Prop. 2.1.45. For labour, see e.g. Catull. 22.7 and the description of the production of Cinna's Smyrna at Catull. 95.1-3. For polishing, see e.g. Catull. 1.1-2, 22.8; Prop. 3.1.8; Hor. Ep. 1.20.2; Ps.-Tib. 3.1.10; Ov. Tr. 1.1.11; Mart. 1.66.10-12.

56 Uses of $\pi \lambda \alpha \dot{\theta} \omega$ : e.g. 'Sculptor of Tyana', 16, 'December 1903', 6, 'At the café door', 5, 7; for $\sigma \chi \eta \mu \alpha \tau i \zeta \omega$, see e.g. 'The funeral of Sarpedon', 20. Cf. the sensual use of $\xi \alpha \nu \alpha \gamma \gamma i \zeta \omega$ at 'Sculptor of Tyana', 11.

57 'Kaisarion', 16-20.

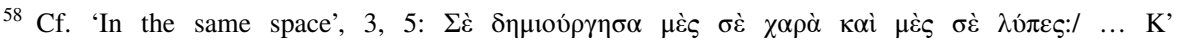

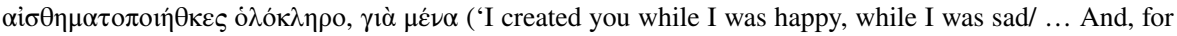
me, the whole of you has been transformed into feeling').

59 Cavafy's focus on the process of poetic creation is reminiscent of ancient discussions of poiesis ('artistic production'); see Arist. EN 1140a, Pol. 1253b-1264a; Hor. Ars 1-37. See also N. A. Greenberg, 'The Use of Poiema and Poesis', HSPh, 65.1, 1965, pp. 263-89.
} 
imagination, then, even queer identity is characterized as constructed by the same language which constructs visual arts.

Ancient statues represent a number of different things to Cavafy, including the eternal memorializing of homoerotics and the ability to present them unabashedly in a public setting. The statue is always a stand in, a substituting symbol for an absent presence. ${ }^{60}$ For the twentieth-century Cavafian persona, gazing at the publicly displayed statue of a beautiful Hellenistic ephebe, it is a stand in for being able to perform his own queer identity in public, as he believed the Greeks of the past were able to. ${ }^{61}$ The queer sculptures of Cavafy's poetry occupy a liminal phase between indestructible stone and vulnerable flesh, entities whose impermanence Cavafy understands, but unavoidably seeks to deny behind a marble veneer. The censured desire for transient youth is represented as something both permitted and eternal in Cavafy's sculptural poetry.

The poet's use of the diegetic creative act (i.e. the presence of actual statuary) extends to the level of his poetics, ${ }^{62}$ to the extent that sculpture and the beautiful bodies it entails are intimately interwoven with his mode of discourse. Because these diegetic sculptures feature objects of desire who are male and for whom 'real' attraction would be illicit, when the sculptural discourse reaches the level of mode, the poetics themselves become queer. As Giannakopoulou has argued, many modern Greek poets use sculpture not only in their content, but also at the level of conceptualizing their creative process. This takes on queer articulations in Cavafy because the statues of his poetry are homoerotic. Homoerotic male sculpture is not an incidental feature of Cavafy's poetry; it is integral to the constitution of his poetics' queer 'angle to the universe'.

\footnotetext{
${ }^{60}$ R. Neer, The Emergence of the Classical Style in Greek Sculpture, Chicago (IL), 2010 pp. 30-1.

${ }^{61}$ It is a not uncommon trope in fin-de-siècle and early-twentieth-century writings (and indeed writings of all eras) for queer people to look back to Classical exempla for evidence of their own desires. Ancient Rome and the Construction of Modern Homosexual Identities, ed. J. Ingleheart, Oxford, 2015, p. 3 n. 2, for instance, discusses the late Victorian trope of the importance of reading Plato through a queer lens as a part of constituting a homosexual identity in, e.g., Forster's Maurice and Wilde's The Portrait of $\mathrm{Mr}$ W. H.; see my comments above on the use of Plato's Charmides in 'In a town of Osroini'. This is akin

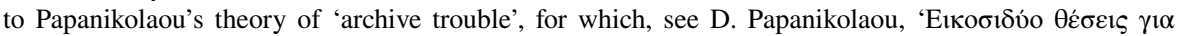

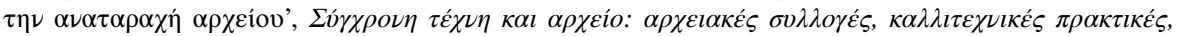

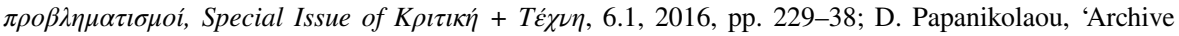
Trouble, 2017', in Culturescapes: Archaeology of the Future, ed. K. Botanova et al., Basel, 2017, pp. $38-52$.

${ }^{62}$ Cf. how comparatively little sculpture there is in Cavafy's prose-it seems to have been a poetic fascination; see Giannakopoulou, Power of Pygmalion (n. 16 above), p. 97. The exception is the prose works

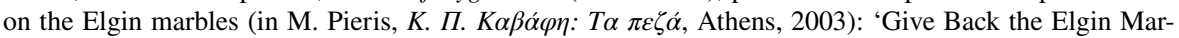

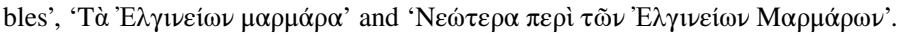




\section{Queering Sculpture}

To talk of 'queering' implies an active engagement by an author, not simply a passive reception of homoerotic history. ${ }^{63}$ It is a process of taking the origins of queerness in the ancient world-origins which themselves may not represent any explicitly queer characters ${ }^{64}$ — and recasting them into queerer, twentieth-century moulds. In discussing this queer turn, I follow Sara Ahmed's Queer Phenomenology. Ahmed discusses the complex relations between objects in the world and queer phenomenological orientations towards them; her primary example is a table, arguing that she has 'made the table a rather queer object by attending to it' ${ }^{65}$ For Ahmed, phenomenological queering is a process in which jilted orientations may be taken to proximal objects, where the quotidian is rearticulated from a queer angle; ${ }^{66}$ statues from ancient Greece may not be quotidian objects in everyday life, but they are, as Giannakopoulou has demonstrated, a conventional feature of modern Greek poetry. Cavafy, then, as I shall demonstrate, orients himself to these unexceptional motifs from a distinctly queer angle.

The locus classicus for such queer manipulation in Cavafy is 'Kaisarion' (see above), but I will explore the more unambiguously sculptural poem 'Before the statue of Endymion', which displays techniques which I suggest are present throughout the corpus:

\begin{tabular}{|c|}
\hline 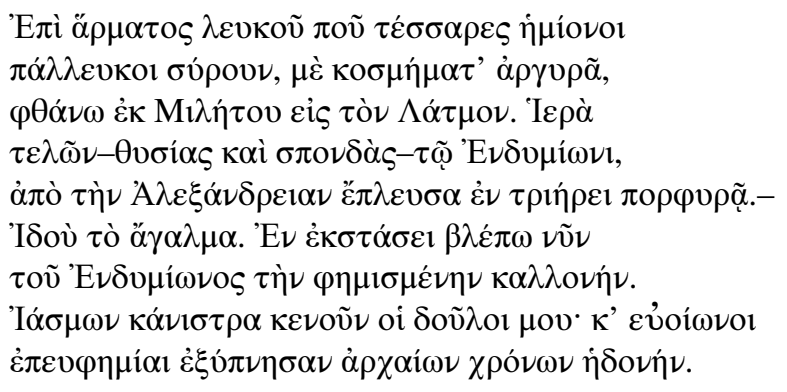 \\
\hline
\end{tabular}

I've come from Miletos to Latmos

on a white chariot drawn by four snow-white mules,

all their trappings silver.

I sailed from Alexandria in a purple trireme

\footnotetext{
63 S. Ahmed, Queer Phenomenology: Orientations, Objects, Others, Durham (NC), 2006: 'to make things queer is certainly to disturb the order of things' (p. 161).

${ }^{64}$ For instance, Kaisarion, in the eponymous poem, is the object of homoerotic desire, which does not reflect any ancient source. One of Cavafy's sources for the poem was Plutarch's account (Vit. Ant.,

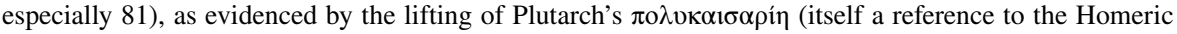

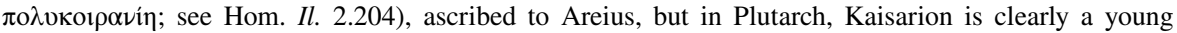
child, devoid of sexually attractive features. Plutarch cannot have been Cavafy's only inspiration for 'Kaisarion' (see T. Kayalis, 'Cavafy's Historical Poetics in Context: “Caesarion” as Palimpsest', The Journal of Modern Hellenism, 34.1, 2019, pp. 43-69 [especially pp. 45-6]), but he is a key part of the picture.

65 Ahmed, Queer Phenomenology (n. 63 above), p. 166.

66 Ibid., especially pp. 86-7.
} 
to perform secret rites-

sacrifices and libations-in honour of Endymion.

And here is the statue. I now stare

at Endymion's famous beauty in wonder.

My slaves empty baskets of jasmine

and auspicious tributes revive the pleasures of ancient days.

Cavafy's subject choice here is no accident. Endymion is a classical figure who had already been subject to queering by other nineteenth-century poets. For instance, Wilde had written an 'Endymion', 67 in which he devotes a queer attention to the Aeolian ephebe, and which employs a similar colour palette to Cavafy's own. Wilde uses a wider range of colours than Cavafy (see below), but prominent among them are purple $(10,24,38)$ and silver (39). In Carpenter's Narcissus, the eponymous youth is lavished with (homo-)eroticized praise which Carpenter explicitly likens to Selene's appreciation for Endymion. Thus, Cavafy's erotic Endymion also picks up on other queer Endymiones of the nineteenth century. ${ }^{68}$ I turn now to Cavafy's 'Before the statue of Endymion'. There are two features of this poem which are striking: the first is the abundance of colour imagery, the second is the atypically antique feel to Cavafy's poetic 'I'. First, the colours. The Cavafian persona aligns himself with a bleached colour palette: he rides a white chariot (' $\alpha \rho^{\prime} \mu \alpha \tau \sigma \varsigma \lambda \varepsilon v \kappa o v$ '),

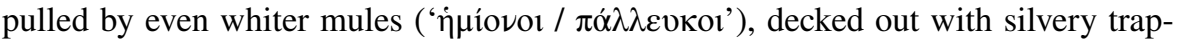

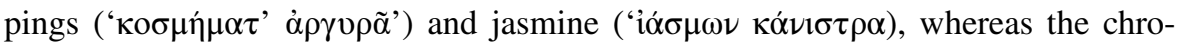

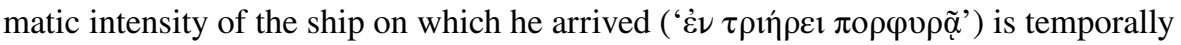
distanced and does not belong to the speaker as directly. The persona, then, carves his image out as chromatically statuesque, in some sense mirroring the sculpture to which he is travelling and casting himself as the same sort of queered, antique body.

The almost erotic kinship between the Cavafian speaker and the statue is brought

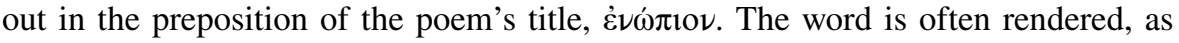
in the Keeley and Sherrard translation I print, as 'before', but its sense is somewhat stronger and more intimate: 'face to face with'. The word's origin in "ै\% ('face') evinces the parallels which Cavafy delineates in his description of the interaction. Given the typical pose of an Endymion (see below), to be literally face-to-face with Endymion, the speaker would have to be laid on top of the statue, creating a deeply sexual image. 'Evஸ́лıо is a later edit: Cavafy's original draft of this poem used $\pi \rho o$ ('before'), ${ }^{69}$ but the change to $\dot{\varepsilon} \nu \omega ́ \pi ı \nu$ marks a conscious repositioning of the speaker from the polite positioning of a museum visitor to a distinctly queer articulation. Cavafy's reorientation to the statue reflects a literally spatial perversion of the

\footnotetext{
${ }^{67}$ Ekdawi, 'Mythical Ephebes' (n. 3 above), p. 42 proposes that Cavafy's poem is modelled on Wilde's.

68 See Keats's 1818 poem Endymion, in which, despite the titular character's mainly heterosexual encounters, there is a queer sensibility to the poet's description of him (e.g. 1.1-3, 'a thing of beauty is a joy for ever: / its loveliness increases; it will never / pass into nothingness', or 1.36-7, 'the very music of the name [Endymion] has gone / into my being'). The Keatsian persona, like the Cavafian, approaches by boat (1.46-9, 'I'll smoothly steer / my little boat, for many quiet hours, / with streams that deepen freshly into bowers'). Cavafy was familiar with Keats's poetry; see his essay $\Lambda \alpha \alpha \mu \alpha$ on Keats's poem 'Lamia' (printed in Pieris, T $\alpha$ $\pi \zeta \zeta \alpha$ [n. 62 above]).

${ }^{69}$ Savidis, $\pi$ oı $\mu \alpha \tau \alpha A^{\prime}$ (n. 6 above), p. 153.
} 
typical, or heterosexual, interaction a viewer would have with it, echoing Ahmed's queer phenomenology. ${ }^{70}$ His interaction with the statue of Endymion is posed as an intimate-and literal-tête-à-tête between a subject who is as white as a statue and a sculpted object who is presented as lifelike.

Now, the poetic ego. The narrator of a Cavafian poem is usually a twentieth-century Alexandrian bringing the past to his modern world; in 'Before the statue of Endymion', the speaker appears to belong to the ancient world of the eponymous statue. He arrives by chariot and trireme, and then performs elaborate rites with a retinue of enslaved people: hardly the trappings of a modern man. This archaizing persona brings me back to my earlier comments on Cavafy's desire to find his place on a queer continuum from the ancient world to his own days; in a poem which has Cavafy gaze at - though not describe in detail-a highly eroticized male body, he takes pains to stress that the voice vocalizing the description is a distinctly ancient one, exculpating the modern poet from his 'ancient' desires. In another poem set in the ancient world, 'Of the Jews (A. D. 50)', Cavafy sculpts another beautiful boy,

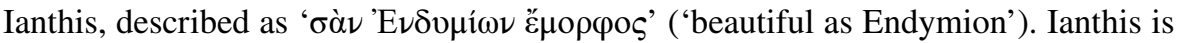
coded as engaging in homosexual affairs, something which he associates with sculp-

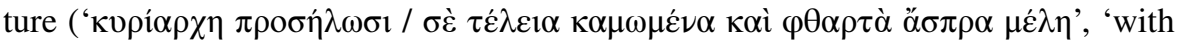
its over-riding devotion / to perfectly shaped, corruptible white limbs'), maintaining an association between Endymion, statuary and queerness throughout the Cavafian corpus. Notions of queer counterculture emerge here, too, as Ianthis swears off his homoerotic life-even in AD 50, queerly associated with ancient Greek sculpture-due to the religious pressures of Judaism, before inevitably re-entering the hedonistic world of homoerotics. The following discussion of 'Before the statue of Endymion', then, is coloured by an understanding of these twin Cavafian lenses: self-inscription into a broader discourse of queer poetry about Endymion and a selfconsciously archaizing persona which excuses the poem's eroticism.

My main focus regarding 'Before the statue of Endymion' is that Cavafy queers the myth of Endymion and that he does so through the medium of queered sculpture. As with most Greek myths, Endymion's story varies somewhat between accounts, but the dominant theme is his love for the moon goddess Selene and her attempt to preserve his beauty forever by putting him into an eternal slumber. In most versions, Selene beseeches Zeus to allow Endymion to exist in perpetual sleep rather than dying, and then sleeps with him in his helpless state, to father some fifty children. ${ }^{71}$ However, Cavafy's statue of Endymion is not the subject of female desire, but rather of ecstatic male gaze; Keeley and Sherrard's translation irons out some

\footnotetext{
$\overline{70}$ Ahmed, Queer Phenomenology (n. 63 above), especially pp. 78-9.

71 Although Endymion's profession alternates between being a hunter, shepherd or king in different accounts, the general narrative outlined above is preserved in $\Sigma$ Theoc. 3.49, Theoc. 20.37, Serv. in $G$. 3.391, Paus. 4.1.4, Sappho fr. 199, Apoll. Rhod. 4.57-8, Luc. DDeor. 19. In an alternate version, seemingly initially at Licymn. 4, but expanded at Ath. 13.564c-d, Endymion is the object not of Selene's love, but of the male god, Hypnos. Whether Cavafy was aware of this somewhat obscure homoerotic account of the myth is unclear.
} 
of the eroticism in the scene. The interaction is posed as a voyeuristic sight, ${ }^{72}$ with the verb $\beta \lambda \varepsilon \dot{\varepsilon} \omega$ ('I gaze') focusing in on the singularity of the speaker's perception and narrowing the scope of the poem to the speaker's subjective, erotic reaction to the male nude before him. By focusing on the speaker's reaction, rather than the statue's appearance, Cavafy fosters a deep intimacy between his persona and Endymion, an intimacy from which even the audience is excluded. This singularity of Cavafy's gaze is highlighted by the obscurity of the image. Endymion is never described physically; ${ }^{73}$ unlike the visually busy first five lines, full of colour, the

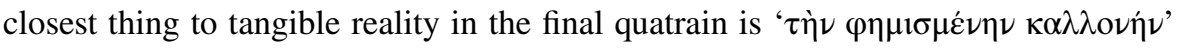
('the renowned beauty'). Cavafy does not even describe the statue's pose, material or colour, which is especially significant in light of the typical posture of Endymion statues (see below). ${ }^{74}$ Keeley and Sherrard's 'in wonder' underplays the orgiastic

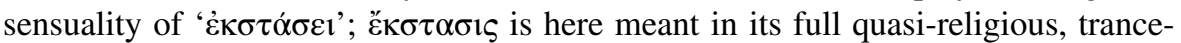
like reverence, ${ }^{75}$ a deeply personal connection to the carved body which can only be fully understood by the male voyeur. Indeed, ecstasy is a particularly queer emotional response, as Muñoz discusses, and here it seems to have that force, creating a unifying and 'expansive version of temporality'. ${ }^{76}$

Endymion was a popular muse for Classical artists, especially on the sides of sarcophagi, and several works featuring him remain extant. Common to most of

\footnotetext{
72 For the erotic voyeurism of sculpture in Cavafy, see Giannakopoulou, 'Moulded by Eros' (n. 16 above), p. 80. For Cavafy's appropriation of the voyeuristic stance from Hellenistic epigram, see K. Gutzwiller, 'Visual Aesthetics in Meleager and Cavafy', CML, 23.2, 2003, pp. 67-87 (67); see also S. Goldhill, 'The Naive and Knowing Eye: Ecphrasis and the Culture of Viewing in the Hellenistic World', in Art and Text in Ancient Greek Culture, ed. S. Goldhill and R. Osborne, Cambridge, 1994, pp. 197-223.

73 Jeffreys, 'Aesthetic' (n. 30 above), p. 68. Cf. Vlastos's derisive comment that Cavafy's poems are 'like pedestals ... from which the statues are missing' and Seferis's later reclamation of the comment to refer to Cavafy's privileging of the idealized statue over the concretely physical: G. Seferis, 'Cavafy and Eliot-A Comparison', in The Mind and Art of C. P. Cavafy: Essays on His Life and Work, ed. D. Harvey, transl. R. Warner, Athens, 1983, pp. 60-88 (77). V. A. Caires, 'Originality and Eroticism: Constantine Cavafy and the Alexandrian Epigram', Byzantine and Modern Greek Studies, 6.1, 1980, pp. 131-55 (146-8) sees a coy furtiveness in Cavafy's economic approach to specifics.

74 The whiteness in this and other poems (especially 'I've looked so much...'; see below) has been seen as hinting at the whiteness of marble (e.g. Giannakopoulou, Power of Pygmalion, [n. 16 above], p. 144), but it is clear that ancient statues were often painted (e.g. E. Hel. 262-3: $\varepsilon \imath^{\prime} \theta^{\prime} \dot{\varepsilon} \xi \alpha \lambda \varepsilon 1 \varphi \theta \varepsilon \tau \tilde{\tau} \sigma^{\prime} \dot{\omega} \varsigma$ ö $\gamma \alpha \lambda \mu$ '

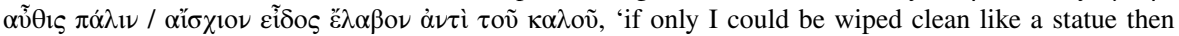
repainted anew, and take on a shameful appearance, rather than one of beauty'). See also S. Woodford, An Introduction to Greek Art, London, 1986, pp. 173-4 and R. M. Cook, Greek Art: Its Development, Character and Influence, London, 1972, pp. 75-6, 88, 93-4 and 99. The extent of Cavafy's awareness of this is debatable, as he seems to approach sculptural imagery as something concerned with whiteness. Cavafy's beliefs about the whiteness of sculpture may have come to him from Winckelmann, with whom he was familiar via the essays of Walter Pater, which were in his possession, see Giannakopoulou, The Power of Pygmalion, pp. 30-1. For Winckelmann's views, see J. J. Winckelmann, History of the Art of Antiquity, transl. H. F. Mallgrave, Los Angeles (CA), 2006, pp. 245-6.

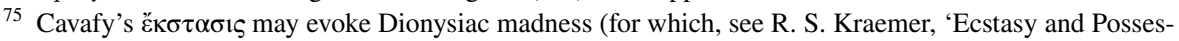
sion: The Attraction of Women to the Cult of Dionysus's, HThR, $72.1 \&$ 2, 1979, pp. 55-80) or even the Neoplatonic mode of moving beyond corporeality and closer to the divine (for which, see T. Alekniené, 'L' « extase mystique » dans la tradition platonicienne: Philon d'Alexandrie et Plotin', StudPhilon, 22.1, 2010, pp. 53-82).

76 Muñoz, Cruising Utopia (n. 11 above), pp. 25-32 (quotation p. 32).
} 
these is the sensual image of the reclining male nude, 'posed in an inviting position' and receptive to sexual entreaties, as may be seen in the second-century AD statue below: ${ }^{77}$

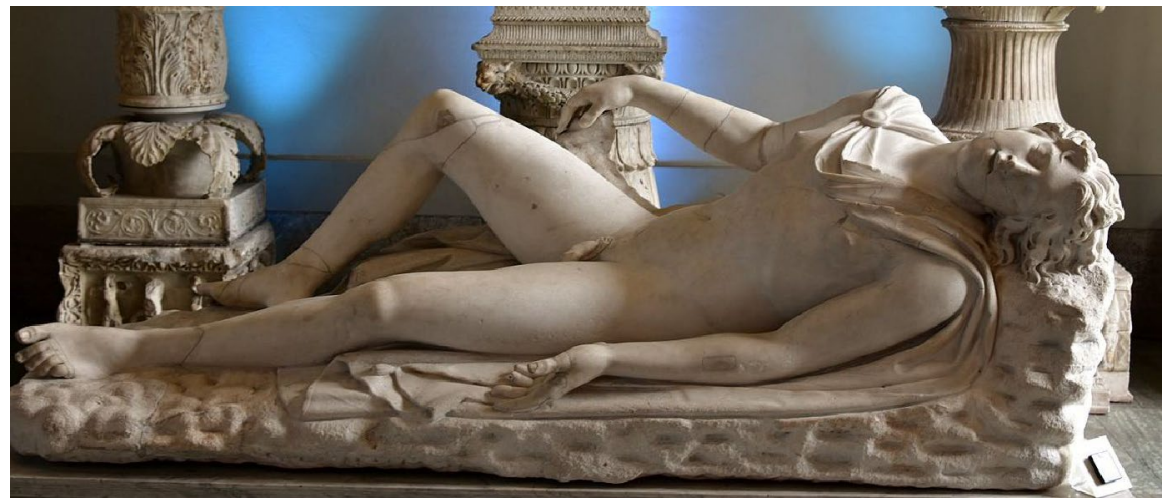

Anonymous. (Second century AD). Statue of Endymion. [Marble] Stockholm: Gustav IIIs Antiksmuseum. ${ }^{78}$

The recumbent pose initially represented Endymion's passivity with respect to the female agency of Selene, but when the distinctly male and homoerotic narrative voice of Cavafy appropriates this image, Endymion becomes an archetypal submissive ephebe vis-à-vis Cavafy's masculine attention. Giannakopoulou reminds us that the real sculptures which inspired Cavafy's poetry could not, during the poet's lifetime, usually be found in the locations where the ancients had placed them (e.g. in this case, Mt. Latmos) but were to be found in museums and publicly accessible workshops $;{ }^{79}$ this suggests to me that the statue of Endymion with which Cavafy would have been most familiar, and which is plausibly the inspiration for this poem,

\footnotetext{
77 Jeffreys, 'Aesthetic' (n. 30 above), p. 68. This pose is common in Classical depictions of the Endymion story, see, the entries under LIMC 3.1, 726-42. The position is described by Selene at Luc.

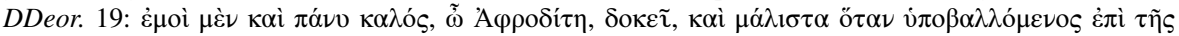

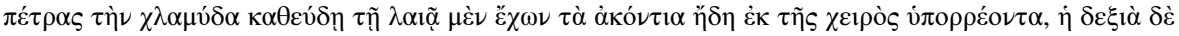

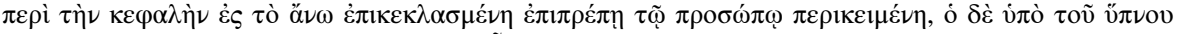

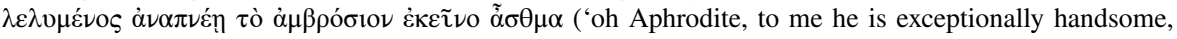
especially whenever he lies down to sleep, casting his cloak on the rock, with the left hand holding his javelins, already slipping through his fingers, and the right curved upwards around his head and whenever he draws attention to his face, by framing it, that boy loosened by sleep, and whenever he breathes that immortal breath').

78 Photograph by Richard Mortel distributed under a CC-BY 2.0 licence.

79 Giannakopoulou, Power of Pygmalion (n. 16 above), p. 99.
} 
is the similarly erotic marble held at the British Museum, ${ }^{80}$ which he had often visited during his youth in England. ${ }^{81}$

The classicizing nude male body is an acceptable object of admiration in art, whose sheer eroticism had somewhat lessened in the eyes of a general Victorian audience; its queerness becomes a sort of erudite cipher among intellectuals who more solidly understood how and why male nudes were so celebrated in the ancient world: a secret knowledge about which marked one as queer. ${ }^{82}$ Cavafy uses the classical nude as a marker like Wilde and Pater's use of music, ${ }^{83}$ something which denotes the queerness of the scene but only to a knowing audience. The sexualized, beautiful marble works neatly for a man in Cavafy's position: he can celebrate a body like Endymion's with an apparently detached scholarly aestheticism, without having to directly vocalize 'the love that dare not speak its name'. ${ }^{84}$

'Before the statue of Endymion' presents an archaized poetic ego for Cavafy, 'remembering' a Hellenistic body through the lens of hedonalgia, but far more common is the poem which imports the aesthetics of classical sculpture into Cavafy's contemporary Alexandria. As an example, I discuss 'At the café door':

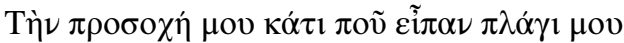

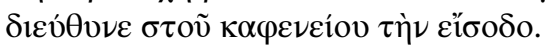

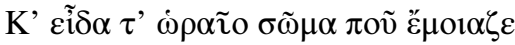

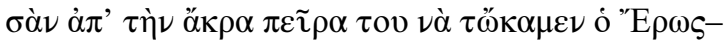

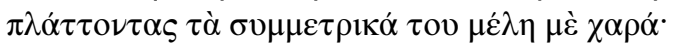

${ }^{80}$ At time of writing, the British Museum's Endymion (museum number 1805,0703.23) is not on display: it was last publicly on display in Italy in 2015 (see the museum's digital catalogue at https://web. archive.org/web/20210226170752/https://www.britishmuseum.org/collection/object/G_1805-0703-23). Museum catalogues contemporaneous with Cavafy's youth suggest both that the identification of this statue-which was previously thought to be of Apollo, Mercury, Atys or Adonis-as Endymion was certain by the time of Cavafy's hypothetical visit and that the statue was on display in the Third Græco Roman Room: see the functionally identical entries for the statue in British Museum, Synopsis of the Contents of the British Museum. Department of Greek and Roman Antiquities: Groco-Roman Sculptures, Vol. I, London, 1874, pp. 52-3 and A. H. Smith, A Catalogue of Sculpture in the Department of Greek and Roman Antiquities of the British Museum, Vol. III, London, 1904. The Synopsis of 1856 (British Museum, Synopsis of the Contents of the British Museum, 63rd edn, London, 1856, p. 95) hesitantly identifies it as Endymion and proves that the statue was on display in what was then called the Third Græco Roman Saloon before Cavafy first arrived in England (see below). For more on this statue, see M. Bieber, The Sculpture of the Hellenistic Age, 2nd edn, New York (NY), 1955, p. 145 and P. Zanker, Klassizistische Statuen: Studien zur Veränderung des Kunstgeschmacks in der römischen Kaiserzeit, Mainz, 1974, p. 113.

${ }^{81}$ See Jeffreys, 'Aesthetic' (n. 30 above) for a series of relationships between Cavafy and the art both of his contemporaries and which was contained in $20^{\text {th }}$ century museums. The Cavafy family had been in England since 1872 and had moved to London in 1874 (see Hirst and Mackridge, C. P. Cavafy [n. 5 above], p. xlv), meaning he could have seen the statue.

${ }^{82}$ See Gutzwiller, 'Visual Aesthetics' (n. 72 above) p. 71.

${ }^{83}$ See Ekdawi, 'Mythical Ephebes', (n. 3 above), p. 42; P. F. Behrendt, Oscar Wilde: Eros and Aesthetics, London, 2016, pp. 33-6: "by the later 1890s, the term "musical" had become a euphemism, in England, for homosexuality ... for homosexuals like Pater and Wilde, ... music seemed to provide the appropriate metaphor for the secret homosexual self' (quotation p. 35).

${ }^{84}$ Gutzwiller, 'Visual Aesthetics' (n. 72 above), p. 84. The famous quotation is from Douglas's 'Two Loves'. For more queer interpretations of Endymion, see my n. 68. 


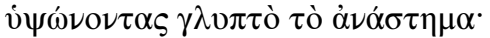

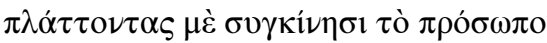

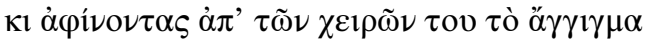

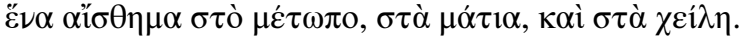

\section{Something they said beside me}

made me look toward the café door,

and I saw that lovely body which seemed

as though Eros in his mastery had fashioned it,

joyfully moulding its well-formed limbs,

raising the statue to its sculpted height,

moulding its face tenderly,

and leaving, with a touch of the fingers,

a particular nuance on the brow, the eyes, the lips.

[Italics denote my alterations to Keeley \& Sherrard's translation]

The poem is rich in sculptural lexis, with the present participle $\pi \lambda \alpha$ ó $\tau \tau o \nu \tau \alpha \varsigma$ ('moulding') twice repeated emphatically to reinforce this theming $(5,7){ }^{85} \mathrm{How}$ ever, the poem differs dramatically from 'Before the statue of Endymion': unlike Endymion, the unnamed boy is alive, not petrified, and lives in Cavafy's contemporary Alexandria, not the mythic Greek past; the encounter is chance, not predicated on extensive premeditated preparation, and the somewhat elusive sensuality of Endymion's marble is solidified in the boy's flesh. The unnamed beloved of this poem is subjected to an almost pornographic gaze, ${ }^{86}$ which parses the youth's body limb-by-limb as a series of erotic body parts: torso, arms, face, brow, eyes, lips. ${ }^{87}$ The transformation of flesh into image fixes the young man as a series of snapshots: vitally dynamic but motionless like a statue. The stillness of these snapshots renders them as discrete moments accessible to the poet when re-examining the hedonalgic landscape of his poetic, sculpted memory.

Unlike the spectre of Kaisarion which Cavafy calls up in the eponymous poem, in 'At the café door', the role of sculptor is played not by the narrator, but by the boy-god of love, Eros. Significantly, the antique deity is not the feminine love-god

\footnotetext{
${ }^{85}$ See also the use of $\gamma \lambda \nu \pi \tau$ ó ('sculpture') and $\mu \varepsilon \dot{\tau} \omega \pi$ o ('brow'), which aurally evokes the $\mu \varepsilon \tau$ ó $\pi \eta$

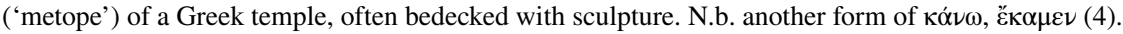

${ }^{86}$ For issues of photography and cinematography in Cavafy, see C. A. Tsakiridou, 'The Photographic Dimension in Some Poems of C. P. Cavafy', Journal of the Hellenic Diaspora, 7.2, 1991, pp. 87-95.; E. Papargyriou, 'Cavafy, Photography and Fetish', Kó $\mu \pi \circ \varsigma$ : Cambridge Papers in Modern Greek, 18.1, 2001, pp. 73-91. As Papargyriou elucidates, the four poems which explicitly feature photographs ('Thus', 'The bandaged shoulder', 'From the drawer' and 'The photograph') all feature erotic images of young men, sometimes explicitly described as pornographic; matters photographic, for Cavafy, are tied up with the salacious, the sexy and, above all, the secretive.

87 This montage of sexualized body parts features in many Cavafian poems, see Jeffreys, 'Aesthetic' (n. 30 above), p. 71: e.g. 'Longings', 'Long ago', 'In the street', 'Grey', 'I've looked so much' (for which, see below), 'Days of 1903', 'The window of the tobacco shop', 'Comes to rest', 'In an old book', 'Picture of a 23-year old painted by his friend of the same age, an amateur', 'Days of 1908', 'September, 1903', 'December, 1903'.
} 
Aphrodite, but the male Eros, a god who often facilitates the queering of a scene. ${ }^{88}$ As Gutzwiller elucidates, Cavafy was familiar with the Hellenistic epigrammatist Meleager, which is especially apparent in both poets' utilization of Eros as a queering sculptural topos. ${ }^{89}$ Meleager's poetry overtly references Eros as the sculptor of a beautiful ephebic youth, using vocabulary akin to Cavafy's:

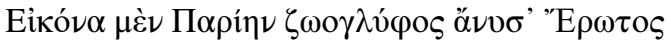

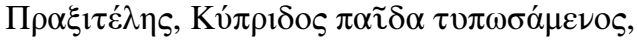

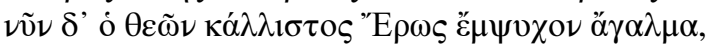

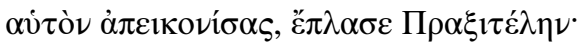

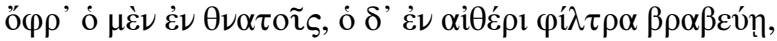

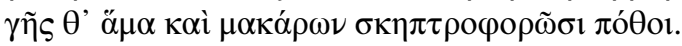

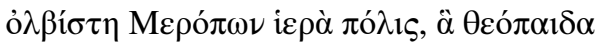

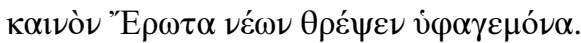

Praxiteles the sculptor made a statue of Eros from

Parian marble, moulding the child of Aphrodite,

but now the most beautiful of the gods-Eros-sculpted an animate

statue of Praxiteles, having sculpted himself;

so that one amid mortals and the other amid immortals might preside over

love,

and so that Loves may respectively bear sceptres on earth as in heaven.

Most blessed is the holy city of the Meropes, which reared

a new Eros, son of a god, to be ruler of the young men. ${ }^{90}$

Cavafy is here reordering and resituating a Hellenistic motif into his world; he develops the theme of Eros-as-sculptor and makes him the metaphorical sculptor of 'At the café door', raised to the level of simile by ع̌ $\mu$ or $\alpha \zeta \varepsilon$ ('seemed'). As the metaphor blossoms out, Cavafy himself becomes both the love-god and Praxiteles, as he sculpts Eros into his poem and is simultaneously emotionally sculpted by his queer desire. Such ideas are present throughout the corpus, for instance, in 'Days of 1896',

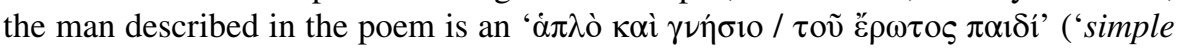

\footnotetext{
${ }^{88}$ See, for instance, J. Ingleheart, 'Amores Plural: Ovidian Homoerotics in the Amores, Ars Amatoria, and Remedia Amoris', in Greek and Latin Love: The Poetic Connection, ed. T. S. Thorsen et al., Berlin, 2021, pp. 189-215 on the reception of $A P$ (Mel.) 12.101 in Ov. Am. 1.1. There is a long tradition in Greek lyric of associating the object of homoerotic desire with Cupid/Eros, see e.g. Anacr. fr. 396, 413; Ibyc. fr. 287; (Mel.) AP 12.127. Kosofsky Sedgwick, 'Cavafy, Proust' (n. 29 above) discusses the importance of divine figures in Cavafy (her 'queer little gods'), arguing that 'the beautiful gods and beautiful young mortals readily exchange functions and even turn into one another', going on to refer to the depiction of Eros in 'He had planned to read' as the 'most ontologically insinuating and tropologically suggestible of the little gods' (p. 50). She eventually identifies Eros as Cavafy's muse throughout his poetry,

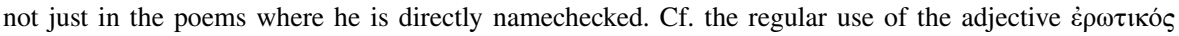
('erotic' or, as Hirst and Mackridge, C. P. Cavafy [n. 5 above], p. xxii translates it, 'made for [E/]eros'), which insinuates the boy god's presence.

${ }^{89}$ Gutzwiller, 'Visual Aesthetics' (n. 72 above). Cf. the tradition of describing statues of Eros (especially the famous statue by Praxiteles) in explicitly homoerotic terms: AP (Mel.) 12.56, 12.57, (Jul. Aegypt.) 16.203, (Praxiteles) 16.204; Prop. 2.19 (for which, see M. Wyke, The Roman Mistress: Ancient and Modern Representations, Oxford, 2002, pp. 62-8).

${ }^{90} A P$ (Mel.) 12.56. See also AP (Mel.) 12.57, 12.110.
} 
and trueborn child of Eros' [my translation]; 16-17), ${ }^{91}$ evoking the same sense of Eros's progenitive and artistic power to create. ${ }^{92}$

The ancient world, especially its statuary, provides a source from which Cavafy creates his own, queer artscape. The plundering of the ancient world is described programmatically in 'I've looked so much...':

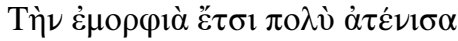

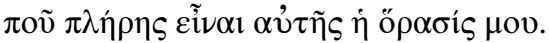

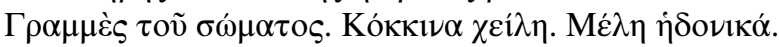

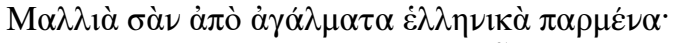

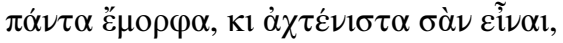

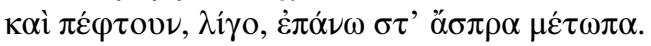

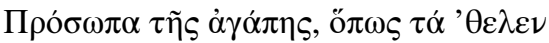

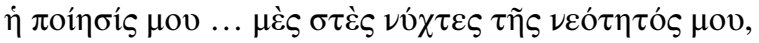

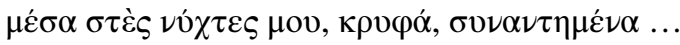

I've looked on beauty so much

that my vision overflows with it.

The body's lines. Red lips. Sensual limbs.

Hair as though stolen from Greek statues,

always lovely, even uncombed,

and falling slightly over pale foreheads.

Figures of love, as my poetry desired them

.... in the nights when I was young,

encountered secretly in those nights

Like 'At the café door', this poem's beloved is a figure sculpted out by Cavafy's queer poetics. The boy's beauty is $\pi \alpha \rho \mu \varepsilon \dot{\nu} \alpha$ ('stolen') from Hellenic sculptures, and the young man's body is a harmonized amalgam of the prima facie opposing states of fleshly sensuality and carved perfection. The boy's limbs are sculpted ö $\pi \omega \varsigma \tau \alpha$

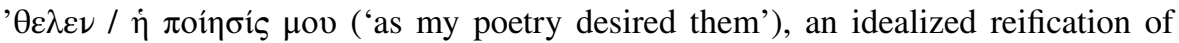
the poetic persona's desires which dances on the threshold between eternal art and sensual, haptic flesh. Of all his poems, this best demonstrates how Cavafy's queer poetics of reception operate in his poetry. The boy is an ideal, without the reifying forces of biography and biology. He is romanticized as the embodiment of that ancient form of love which Cavafy recognized as unacceptable in the world in which

\footnotetext{
91 Cavafy, like the ancient Greeks, plays on the flexibility of the Greek language: although Cavafy clearly wrote ع̈ $\rho \omega \tau \mathrm{\varsigma}_{\varsigma}$ in miniscule in the autograph manuscript $(\mathrm{F} 2, \varphi 15)$, therefore strictly meaning 'love', simply by capitalizing the epsilon, he could have written 'E $\rho \omega \tau$ os, making the connection to the god of love explicit. Such linguistic polyvalence compels us to detect plays whenever Cavafy uses apparently conceptual words, like ع̌ $\rho \omega s$.

92 The created aspect of Cavafian ephebes is highlighted by the sorts of epithets often ascribed to them

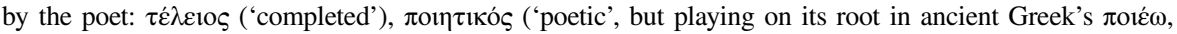

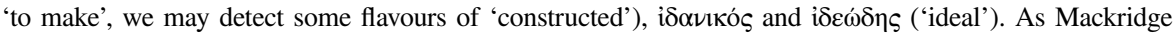
says, these adjectives cast Cavafy's beloveds 'as though they were already an artistic representation: a statue or a painting that has transcended the specific features of its individual model and transfigured it into an ideal embodiment of aesthetic beauty and sexual desire' (Hirst and Mackridge, C. P. Cavafy [n. 5 above], p.

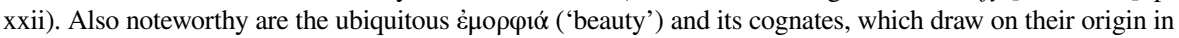

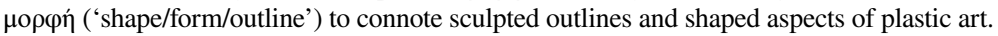


he lived. Cavafy's is not a unique story; sculpture has been used since Winckelmann as a vehicle to negotiate ideas of queerness, ${ }^{93}$ and as Funke and Grove argue:

Because of statuary's power to disrupt present-day ideals and values around gender and sexuality and elicit a strong physical and erotic response, it has often served to develop queer possibilities. ${ }^{94}$

It is so with Cavafy. For him, reappropriation of ancient Greek homoerotics in finde-siècle Alexandria represents a reconnection with his Greek heritage and inheritance-not an inheritance focused on ethical or artistic greatness (as it had been for so many others), ${ }^{95}$ but one derived from a shared queer sensibility.

To conclude, for Cavafy's poetics, sculpture is integral for the topics which it allows him to address. Statues are everywhere in Cavafy: they prominently feature as homoerotic symbols in his poetry but, more profoundly, they are also the mode through which he mediates his reception and rearticulation of ancient Greek desire. Sculpture forms an object of negotiation-on literal and poetic levels - through which Cavafy distils modern Greek queerness. Through his queer poetics, the poet-as-sculptor mines the marble of the classical past and re-sculpts it into the poetry of the twentieth century, reorienting both content and mode as queer. Thus, he is able to destabilize, or at least rearticulate, the meaning of classical sculpture for his own poetic identity formation, simultaneously rendering his poetry, poetics and persona as queer. Forster tells us that Cavafy stood, statue-like, 'absolutely motionless at a slight angle to the universe'. From this stance Cavafy gazes at a present in which those 'made like him' find little foothold; he conceives of a mode which is 'attentive to the past for the purposes of critiquing [this] present', ${ }^{96}$ and with this, he sculpts his queer poetics.

Open Access This article is licensed under a Creative Commons Attribution 4.0 International License, which permits use, sharing, adaptation, distribution and reproduction in any medium or format, as long as you give appropriate credit to the original author(s) and the source, provide a link to the Creative Commons licence, and indicate if changes were made. The images or other third party material in this article are included in the article's Creative Commons licence, unless indicated otherwise in a credit line to the material. If material is not included in the article's Creative Commons licence and your intended use is not permitted by statutory regulation or exceeds the permitted use, you will need to obtain permission directly from the copyright holder. To view a copy of this licence, visit http://creativecommons.org/licenses/by/4.0/.

Publisher's Note Springer Nature remains neutral with regard to jurisdictional claims in published maps and institutional affiliations.

\footnotetext{
93 See many of the chapters in Sculpture, Sexuality and History: Encounters in Literature, Culture and the Arts from the Eighteenth Century to the Present, ed. J. Funke and J. Grove, London, 2019, especially those by Grove, Ventrella, Funke and Mechowski. Many writers, such as Carpenter, Ives and Symonds, claim to have been prompted into queer sentiment by Hellenic statues, see M. Cook, London and the Culture of Homosexuality, 1885-1914, Cambridge, 2003, p. 126. See also J. Ingleheart, 'Responding to Ovid's Pygmalion episode and receptions of same-sex love in Classical antiquity: art, homosexuality, and the Curatorship of Classical culture in E. M. Forster's 'The Classical Annex', Classical Receptions Journal, 7.2, 2015, pp. 141-58.

94 Funke and Grove, Sculpture (n. 93 above), p. 24.

95 E.g. K. Clark, The Nude: A Study in Ideal Form, New York (NY), 1956; see also Funke and Grove, Sculpture (n. 93 above), pp. 17-19.

96 Muñoz, Cruising Utopia (n. 11 above), p. 18.
} 